Прикро. Адже вивчаючи історію розвитку культури, усвідомлюючи зміст основних мистецтвознавчих категорій, студенти змогли б навчитися оцінювати значення для цивілізації, культури людства художньої творчості видатних митців, підвищити суб'єктивну культуру сприйняття творів мистецтва, розвинути естетичний смак, навчитися прогнозувати спрямованість майбутніх культурних процесів. Зрештою, сформувати таку систему культурних орієнтацій та установок особистості, яка б утверджувала пріоритет загальнолюдських цінностей та гуманітарний розвій культури.

Творити життя за законами краси! Чи не таке гасло воліли б ми сьогодні проголосити як визначальне у формуванні всебічно розвинутої творчої особистості, якій до снаги взяти відповідальність за майбутне своєї Батьківщини й людства загалом.

\title{
Література:
}

1. Кримський С. Запити філософських смислів. К.: ПАРАПАН, 2003. $240 \mathrm{c}$.

DOI https://doi.org/10.30525/978-9934-26-004-9-72

\section{BEADING THE WOMANTORY: ART PROJECT AS A WAY TO TELL ABOUT WOMEN'S HISTORY}

\author{
Shcherbina M. M. \\ Ph.D. in Philosophy of Culture, Associated Professor, \\ Associated Professor at the Philosophy Department \\ Kharkiv National Medical University \\ Kharkiv, Ukraine
}

History and mythology are the binder that brings us together, the base for dignity and self-respect. However, women's history often remains hidden from ordinary people. Ukrainian historian Martha Bogachevskaya-Khomyak compared the history of women with traditional embroidery in white and white: the metaphor is sad but true. The purpose of the project for the unique Ukrainian Gendermuseum (the Museim of Women's and Gender History - the creator and director of the museum is Tatiana Isaeva, the author and coordinator of the project is Maria Shcherbina) was a new option to reveal and show the world white faces of women - scientists, artists, human rights activists, writers, 
to color the past and have a hand in making history. The idea was to present women not as an attachment to their children, husbands, brothers and colleagues, but as activists with their own life circumstances, aspirations and achievemens, to paint the past and participate in the hand making of history and an art object, which should be an occasion for educational and popular lectures. The idea was to make an art object from beads.

The big art object was created by the summer of 2017 and presented at exhibitions in Kharkiv and Kiyv. According to the idea of the author of the project, Maria Shcherbina, the prehistoric mollusk ammonite has become a symbol, a metaphor of how people and their lives shape history. 400 million years ago, it swam, and now it still inspires craftswomen and craftsmen. The ammonite was printed on a large canvas $(1 \mathrm{~m}$ by $80 \mathrm{~cm})$, and portraits of the women were spirally arranged on it (the heroines were chosen by the participants of the project). Olga Buyadzhi and Maria Chernaya were involved in the design of the canvases, portraits and booklets of the project. Next to each portrait, a symbol $\left(5 \mathrm{~cm}^{2}\right)$, beaded or embroidered with beads, was placed, it tells about the contribution this person has done for humanity. There are no signatures, but there are museum guides. An art project is an occasion for an educational lecture and mutual education.

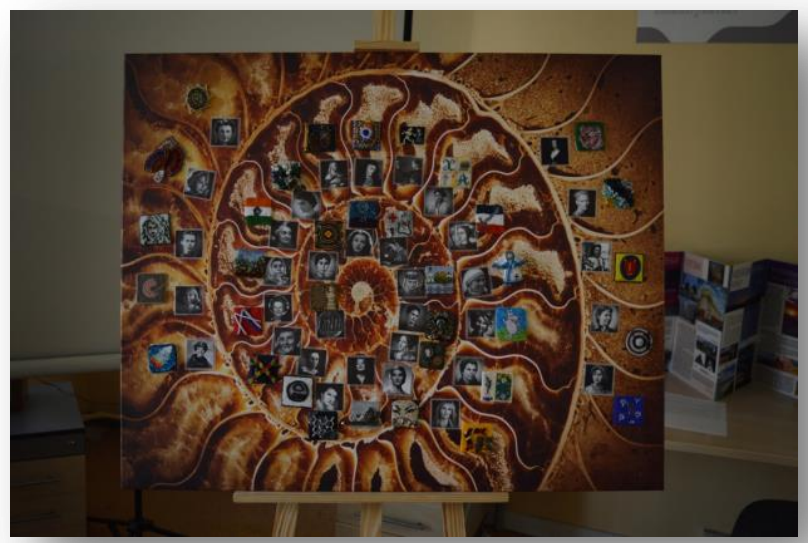

The topic turned out to be so relevant and important that craftswomen and craftsmen from all over the world responded, and the beaded pieces of the project went to Kharkov from Belgium, Belarus, Great Britain, Germany, Russia, USA, Switzerland and, of course, different cities of Ukraine. The result: there were 35 personalities and 34 beaders. 
Maria Shcherbina (Kharkiv), author and coordinator of the project selected the British architect Zaha Hadid, the first woman to be awarded the Pritzker Prize.

Patricia McCourt (London) decided to bead Elizabeth Garrett Anderson the first woman to qualify in Britain as a physician and surgeon openly and the first woman-mayor in Britain;

Huib Petersen (San Francisco, a native of the Netherlands) spoke about his compatriot, the legendary spy Mate Hari.
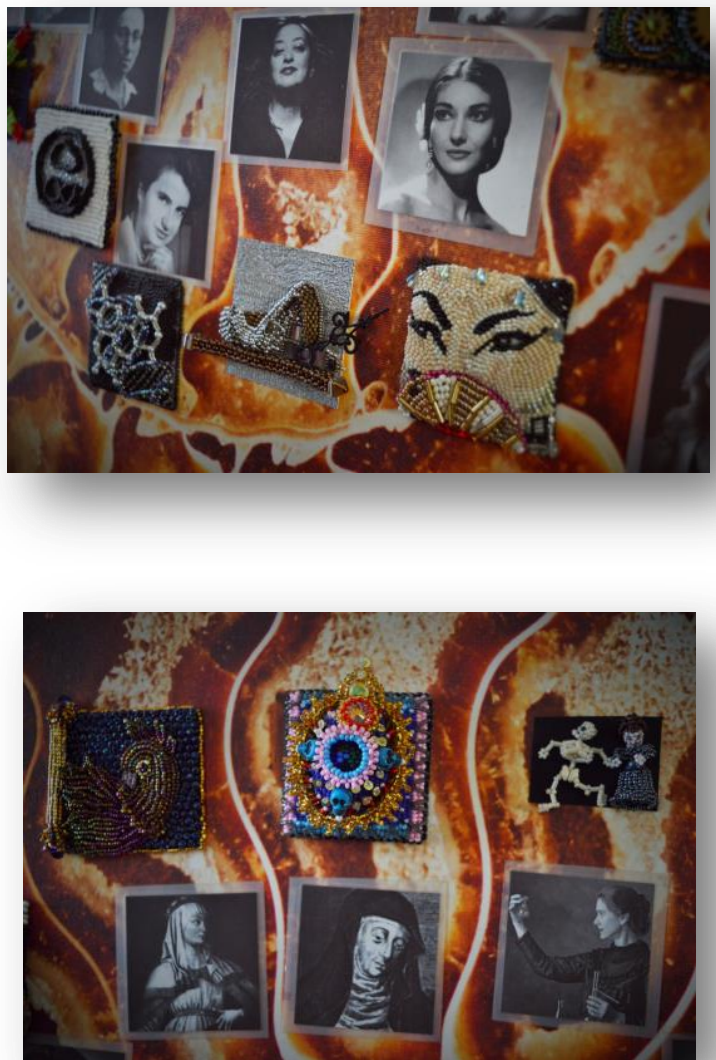

The team of the Lutsk Pedagogical College Gender Education Center (Galina Yerko, Svetlana Virsta and Olga Vanyuk) chose the poet, writer and translator Lesya Ukrainka, the writer Olena Pchilka, the warrior Zhanna d'Ark, 20 
the political activist Indira Gandhi and the Greek scientist and philosopher Hypatia of Alexandria. Olga Milyutina (Kharkiv) settled on the Sumerian Princess, the High Priestess of the goddess Inanna and the moon god Nanna, Enkheduanna, who is the first person in history known as the author of texts and poems. Veronika Zavjalova and Nadezhda Nedashkovskaya (Minsk, Belarus) portrayed their great compatriot, Nobel Prize Laureate Svetlana Aleksievich. Cath Tomas (Gland, Switzerland) sent in a smaller version of Maria Sklodowska-Curie and a skeleton dancing in X-rays. Kharkiv crafter Aleksandra Tildas portrayed the actress Tilda Swinton. Anna Dekhtyareva (Krasnodar, Russia) told about Hedy Lamarr, the inventor of the Wi-Fi and mobile communication principle.

Victoria Zaitseva from Kiyv chose Princess Olga as her heroine. And Iryna Ryzhkova from Kharkiv portrayed her colleague, mathematician Sofia Kovalevskaya. Anna Tsarkova (Kharkiv) made a circular saw, the invention of Tabitha Babbitt, and Yevgeniya Belyaeva portrayed the chidren rights activist and creator of Pippi Longstocking, Astrid Lindgren. Albina Polyanskaya's work is dedication to Coco Chanel which consist from the flowers that make up the heart note of Chanel \# 5, covering the collar of the black dress..

Olena Novikova settled on Ada Lovelace, the first programmer in history, and Saori Abe-Schröder (Dortmund, Germany) chose the legendary Queen Esther as a symbol of a person who opposed genocide. Elina Ivanova (Donetsk-Irpin, Ukraine) created a reproduction of the painting by Katerina Bilokur, and Elena Kolomoets (Ukraine and Sweden) reproduced the fantastic beast of Ukrainian artist, Maria Primachenko.

Maria Shcherbina's students Ksenia Popova, Margarita Banduryan and Elizaveta Kolinko embroidered a rocket for Eileen Marie Collins, the first commander of the Space Shuttle, a Moomin troll for Tuvi Jansson and a flower for the artist Rachelle Ruysch. Rita Person-Vellemans (Lebbeck, Belgium) depicted a portrait of Mother Teresa, Natalia Mariash - a selfportrait of Frida Kahlo. Elena Gasiy dedicated her work to Margaret Thatcher, Inna Bichler - to the algebraist Emmy Noether, Natalia Bichler to the medieval visionary, composer and scientist Hildegard of Bingen.

Olga Loseva made a symbol for Rosalind Franklin, who made a great contribution to understanding the structure of DNA, Olga Limonova embroided the initials of Kharkiv enlightener Christina Alchevskaya, Olga Hrytsenko made the portrait of Maria Callas, Elena Osokina embroidered the cover of Jane Austen's novel. And the youngest participant in the project, nine-year-old Timur Shcherbina weaved a Gryffindor scarf for J.K. Rowling.

The heroines of the project are not only personalities who make history, but also behavioral models, examples and inspirers for those who follow. 
However, the value of the project «Beading the Womantory» is not limited to its direct empirical result - the presentation of role models in the created museum exhibit: the project as a cultural event and a work of art, as a unity of its content, form, its implementation and its final product, which cannot be reduced only to a multifaceted collage installation (see photo 1), but including changes in self-assessments and, more broadly, the life worlds of its participants, should be comprehended from the philosophical-cultural, art history and social (sociological and socio-psychological) points of view. Here are some starting points for possible further analysis.

First, the work has evolved from literal "making history with our own hands" to an art object that, viewed as a whole, carries the meanings of a social poster. But each of the fragments of this beaded "semantic mosaic" is already an independent work of art (the study of the peculiarities of perception of which, that is, the impact on the viewer, can also become an interesting research task), and these pictures are combined into a single patchwork sewing by a meta-idea - refracted the vision of a beader and the idea of creativity and achievements of a specific multifaceted personality embodied in the author's symbolism.

Secondly, the artistic practice of beading is being rethought by itself. From a traditional occupation attributed to women in stereotypical behavioral roles, beaded design develops into an art that independently asserts new meanings. And "women's work" suddenly becomes a women's empowerment, and this aspect deserves both primary attention and further research.Third, the adoption of new norms (including communication and self-perception) redefines the behavioral stereotypes of young women, for whom (possibly as a result of presenting destinies as lectures) the idea of a scientific, artistic or social vocation becomes natural.

Secondly, the artistic practice of beading is being rethought by itself. From a traditional occupation attributed to women in their stereotypical behavioral roles, bead design develops into an art that independently asserts new meanings. And «women's work» suddenly becomes a women's empowerment, and this aspect deserves both primary attention and further research.

Third, the adoption of new norms (including communication and selfperception) redefines the behavioral stereotypes of young women, for whom (possibly as a result of presenting destinies as lectures) the idea of a scientific, artistic or social vocation becomes natural. 